\title{
THE ROLE OF ETHNOGRAPHERS IN THE INVENTION OF SOCIALIST TRADITIONS IN THE LATVIAN SOVIET SOCIALIST REPUBLIC*
}

\author{
ILZE BOLDĀNE-ZEL̨ENKOVA \\ Researcher \\ Institute of Latvian History, University of Latvia \\ Kalpaka Boulevard 4, Riga, LV-1050 \\ e-mail: boldane@lu.lv
}

\begin{abstract}
This study, based on archive document research and analysis of publications by Latvian Soviet Socialist Republic (LSSR) ethnographers, discusses the process of invention and implementation of Socialist traditions and the role of scientists in this. The introduction of Soviet traditions in Latvia did not begin immediately after the Second World War when the communist occupation regime was restored. The occupation regime in the framework of an anti-religious campaign turned to the transformation of traditions that affect individual's private sphere and relate to church rituals - baptism, confirmation, weddings, funerals, Latvian cemetery festivities - in the second half of 1950s, along with the implementation of revolutionary and labour traditions. In order to achieve the goals set by the Communist Party, a new structure of institutions was formed and specialists from many fields were involved, including ethnographers from the Institute of History at the LSSR Academy of Sciences (hereinafter - LSSR AS). Ethnographers offered recommendations, as well as observed and analysed the process, discussing it in meetings of official commissions and sharing the conclusions in scientific publications, presentations, etc.
\end{abstract}

KEYWORDS: socialist traditions • ethnographers • soviet culture and lifestyle • tools of influencing society $\bullet$ anti-religious campaign

\section{IN TRODUCTION}

In 1995, a few years after the Restoration of Independence of the Republic of Latvia, the director of the Institute of Latvian History Indulis Ronis (1943-2016) published an article entitled "The Institute of Latvian History in the Context of History" (Ronis 1995)

* The author's work on this article constitutes a part of the University of Latvia project No. AAP2016/AZ85. 
in which he criticised fellow ethnographers for cooperating with the Soviet authorities and invited them to make a public confession. The main accusation against ethnographers is linked to the invention and/or imposition of Socialist traditions on Latvian society.

Several groups of archival documents have been used to investigate this issue: 1) documents and correspondence revealing the decree of the Council of Ministers (hereinafter - the $\mathrm{CM}$ ) on the implementation of measures in the invention of Soviet traditions; 2) protocols from the Scientific Councils (SC) of the Institute of History and the Institute of Folklore and Ethnography at the LSSR AS, held in the National Archives of Latvia - the State Archives of Latvia (Riga, hereinafter - LNA-LVA), as well 3) the materials documenting the new traditions, including photographs, descriptions of events, documents, etc., which were accumulated in the period from the 1950s to the first half of the 1980s, and are found at the Repository of Ethnographic Materials (here-

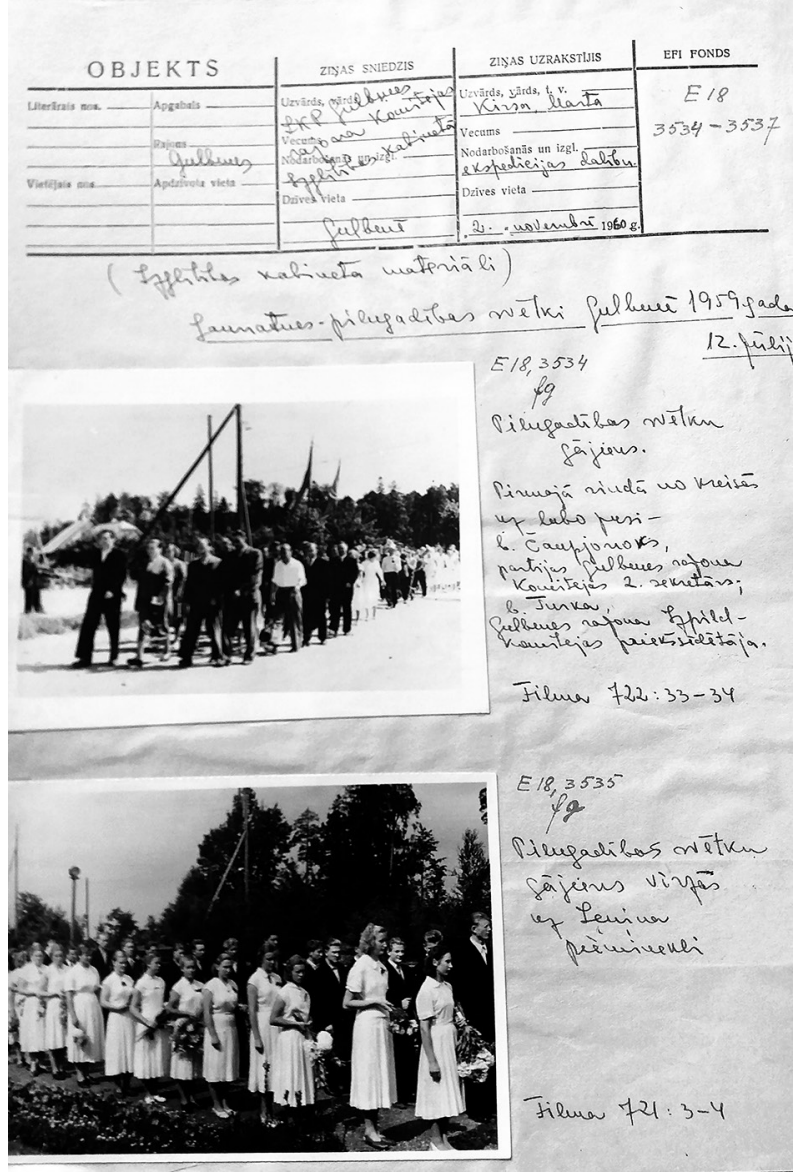
inafter - REM) at the Institute of Latvian History, University of Latvia (Photo 1). Significant contributions to the research were provided by academic publications by Soviet ethnographers included in the collections 1) Archaeology and Ethnography (Arheologiija un etnogrāfija); 2) Theses of Scientific Report Session on Research Results of Archaeologists, Anthropologists and Ethnographers in 1952-1991; 3) Proceedings of the Latvian SSR Academy of Sciences (LPSR Zinātñu akadēmijas Vēstis), as well as collective monographs on the description of socialist lifestyle ${ }^{1}$ and methodological recommendations for the implementation of Soviet traditions ${ }^{2}$.

Photo 1. The page of the expedition. Department of Archaeology and Ethnography. Institute of History and Material Culture at the LSSR AS. Celebration of majority in Gulbene city (1959). 
The terms 'socialist traditions' and 'Soviet traditions' have been used as synonyms in the examined sources and the historiography of the Communist regime. The most recognisable version among the definitions reads as follows:

Socialist traditions are an element of the social and cultural heritage that has been established historically within a certain group of people, has been appropriated from the previous generations and has been passed on further. The processes of Soviet festivities and customs manifest a materialistic worldview, demonstrate the socialist lifestyle and reflect the care that the Soviet state shows for the individual. (Latvijas Padomju enciklopédija 1987: 698)

The purpose of introducing new Soviet traditions was to replace traditional Latvian customs, including the related religious rituals. According to a well-known Communist party slogan - national in form, socialist in content - elements of Latvian traditional culture, ethnography and folklore were used to create a framework the new traditions. At the same time, many elements and outward appearances of religious ceremonies are recognisable in Soviet traditions related to the most important events in person's life baptism, coming-of-age (prazdnik sovershennoletiya) or confirmation, marriage, death.

The initiators of traditions were not the 'working-class masses' as one could read in the official publications of that time, or the local elite, but the highest representatives of the Soviet regime in Moscow. The developers of the new traditions were representatives of the local authorities, who attracted the local representatives of the cultural and science elites, among them ethnographers. The unification and invention of traditions took place gradually, under strict control. 'Allowing' other customs to be practiced in parallel was an element of propaganda aimed to show the world that freedom of faith was practiced in the USSR. However, at the same time all activities carried out in churches were under the strict control of the KGB and subject to active public condemnation.

The importance of common celebrations and commemorative rituals in the ideological upbringing and consolidation of society was an understandable issue for the ideologists of the Central Committee of the Communist Party (Kampars and Zakovich 1967; Zhidkova 2012). However, the creation and implementation as well as the form and content of these traditions took several decades of experimentation, and ultimately attempts were made to eradicate religious rituals from the everyday life of the population. Contemporaries stressed two main reasons for the process of implementing new traditions in the LSSR did not starting in the first years of the Communist regime: 1) economic - rebuilding after the war and stabilisation of the economy, and 2) ideological - the invention of new traditions was a part of a vast antireligious campaign led by the head of the Communist Party (1953-1964) Nikita Sergeyevich Khrushchev (1894-1971). Many commissions and institutions were founded starting at the end of 1950s: the Commission of Soviet Domestic Traditions (1960-1963) undertaken by the Central Committee of the Latvian Leninist Young Communist League (CC LLYCL), ${ }^{4}$ the Sector for Soviet Domestic Traditions, part of the Republic's Atheist Council of the Society of Information of the LSSR; the Commission Monitoring the Introduction of Soviet Domestic Traditions, and the Law on Religious Cults of the CM LSSR (1964-1979), the Commission Facilitating Soviet Traditions, Festivities, Rituals, and the Law on Religious 
Cults of the CM LSSR (started in 1979; LNA LVA 1969-1984). The task of the commissions was to develop, implement and monitor the new socialist traditions and rituals. Members of the Central Committee of the Latvian Communist Party (hereinafter - CC LCP), scientists (ethnographers, folklorists), practitioners (employees at culture centres and registry offices, as well as employees at the institutions providing household services (kommunalnyye uslugi) and representatives of political decision-making bodies and executive bodies were involved in this process (Boldāne-Zelenkova 2017: 127). Branches of the Commission functioned under the auspices of the local Executive Committees of the District, Town, Urban and Village Workers' Deputies; this is where librarians, teachers, club leaders, farmers from collective farms, secretaries of the selsoviets, animal husbandry experts and others joined forces (E 27, 5505; 28, 10380; 29, 4221; 35, 1671-1673ag et al.). The activities of these commissions and their satellite organisations formed a cohesive infrastructure that was the basis for organisational, propaganda and research work. They worked in a coordinated manner with the Academic and Methodological Cabinet in the Activities of Clubs of the Ministry of Culture of the LSSR, and People's House of Art of Emilis Melngailis, ${ }^{5}$ which was the most important gear in the mechanism of invention and implementation of new Soviet traditions.

An important player in this structure of commissions was the Methodological Society of Socialist Traditions (hereinafter - the Society), founded in 1976. The Society started working as part of the Academic and Methodological Cabinet in the Activities of Clubs, with members coming from the Communist Party, Soviet councils and the Young Communist League, as well as institutions for culture, education and academic research. Among the members of the Society were some ethnographers from the Institute of History at the LSSR AS (Photo 2), whose direct duties were related to the creation, improvement and monitoring of festivities and customs, as well as proposals for event improvements (Alsupe and Cimermanis 1985: 166; Cimermanis and Slava 1987). A similar system and methodology for the implementation of Soviet traditions can be observed in the nearest neighbouring countries, i.e. the Estonian SSR (Kalits 1987: 72) and the Lithuanian SSR (Višņauskaite 1987: 112) at that time.

Even before the commencement of the many commissions mentioned above, the first attempts to introduce new festivities, which should have replaced religious rituals such as baptism, confirmation and weddings, took place. Ethnographer Antonina Zavarina (1928-2015) mentions 1954, when a public name-giving celebration (in Valmiera) and a public wedding (in Riga) were held (Zavarina 1970: 197). The accumulated experience of the Republic in organising Soviet festivities and celebrations, as well as the observations and analyses of this process by ethnographers, apparently led to the claim found in the Soviet historiography that the Baltic Republics (the Latvian, Estonian and Lithuanian SSRs) were among the initiators of Soviet traditions (Kampars and Zakovich 1967: 33).

In spite of the involvement of the repressive apparatus of the communist regime, eradicating the importance of the Christian church in people's lives was an impossible mission. As minutes and handouts from Commission meetings, as well as ethnographers' scientific publications, have shown, many of the older generation of the Latvian SSR, especially residents of eastern Latvia (a mainly Catholic region) were still under the influence of 'religious delusions' even in the 1980s (LNA-LVA 270-3-10645: 126-136; Cimermanis 1987: 7). 


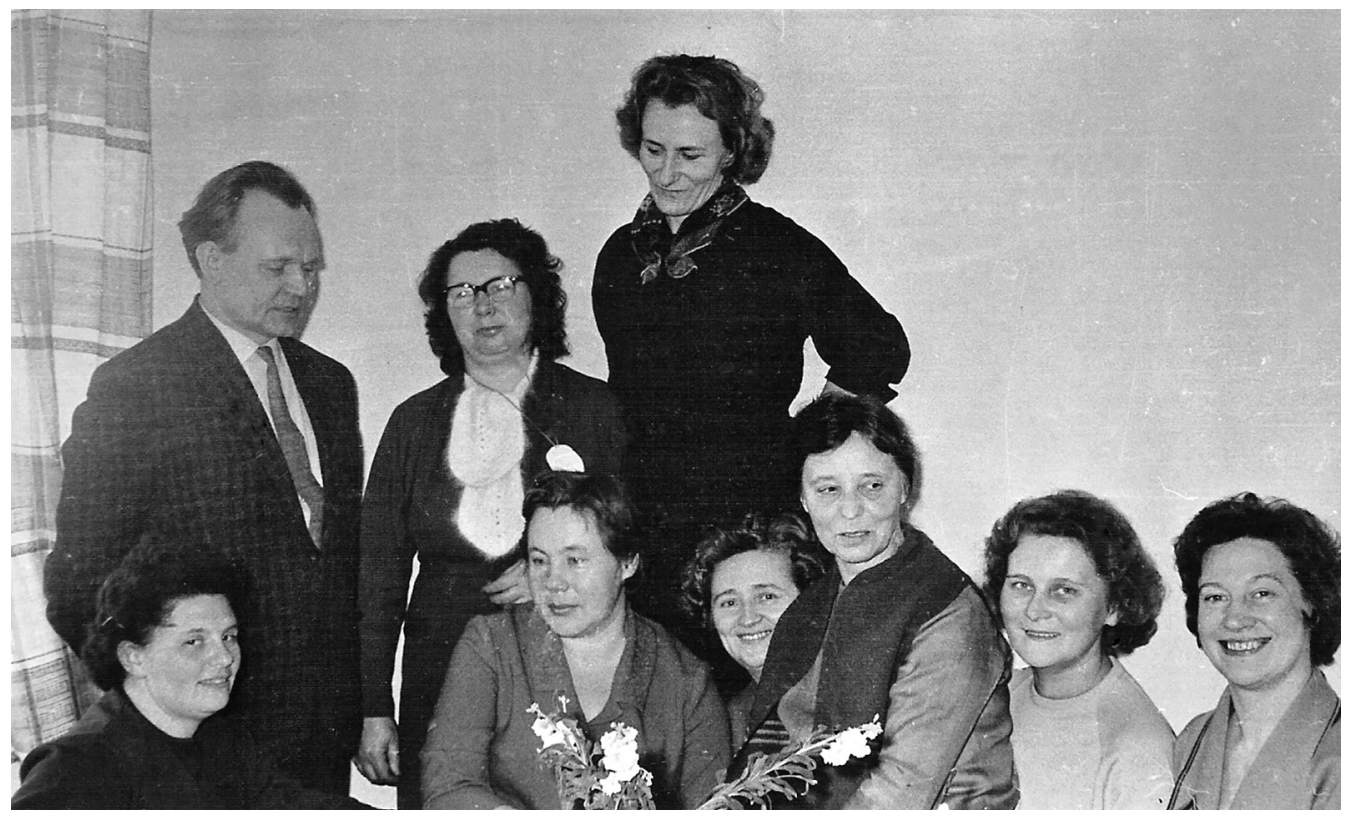

Photo 2. Ethnographers. Department of Archaeology and Ethnography. Institute of History and Material Culture at the LSSR AS. First line from the left: Lidija Jefremova, Elga Čivkule, Antonina Zavarina, Marta Kirša, Aina Alsupe, Linda Dumpe. Second line: head of the department Heinrihs Strods, Mirdza Slava, Anna Krastina. Photo by Saulvedis Cimermanis, 1960s.

\section{THE LIMITED FREEDOM OF ETHNOGRAPHERS TO SELECT RESEARCH OBJECTS}

Unlike folklore, ethnography had no strong tradition of academic research in Latvia: as an independent field of science it began to develop only at the very end of the 1930s under the leadership of Swedish ethnologist Dag Trotzig (Dags Trocigs, 1914-1944). Prior to this, as the historian and head of the Ethnographic Sector of the Institute of History of the LSSR AS Heinrih Strod (Heinrihs Strods, 1925-2012) notes, there was no ethnographic science in the broadest sense of the word, rather there was the field of ethnography, where various scientists and specialists - architects, artists, and philologists - harvested what they could (Strods 1964: 141). Trotzig was an assistant professor at the University of Latvia and, from 1939 until the Soviet occupation, in cooperation with the Board of Monuments (1923-1944) and the Latvian Chamber of Writing and Arts (1938-1940), organised expeditions to collect expressions of the spirit and will of the people. Trotzig was one of the first scholars in Latvia to focus on ethnological, not ethnographic, research. He emphasised, in support of Scandinavian practice, the need for the kind of comparative study of peoples' lives (time, space, social groups) provided by ethnology, rather than the simpler descriptions offered by ethnography (Trocigs 1940: 174-175). Unfortunately, the war stopped this promising start and from then until the end of the 1950s there were no professional ethnographers in Latvia. 
After the Second World War in Latvia ethnology was recognised as a science belonging to the bourgeois world (as was the case across the whole of the USSR), while ethnography found its place in the Academy of Sciences, which at that time had a comparable status to that of a modern ministry (Muižnieks 2019: 4). The main object of ethnographic studies in the USSR was traditional culture, closely related to scientific interest in ethnogenesis. The task of ethnographers became to introduce and resolve practical issues of everyday life (modern ethnic processes, the formation of new nations, the struggle with the remnants of the past, etc.) (Latvijas Padomju Enciklopédija 1983: 223)

The LSSR AS Institute of History was established in 1946, with a very small group of ethnographers (3-5 people) with no appropriate education working there. Following the decision of the Presidium of the LSSR AS, ethnographers changed their institutional affiliation in 1951 and worked as a part of the Institute of Ethnography and Folklore (hereinafter the IEF) until 1955. The lifetime of the IEF fell into the period of Stalinism, which for scientists was very difficult and full of contradictions. At the time ethnographers and folklorists had to learn the main differences between bourgeois and Soviet science, i.e. the bourgeois scientist passively awaited the results of public creativity, while his or her Soviet counterpart initiated the right creativity and controlled the process. In the case of folkloristics the challenge was to invent the collection of Soviet folklore (Kencis 2019). The view in Western countries on the similarities between the two disciplines - folklore and ethnography - was not accepted in the soviet science system. There was a notion that folklore and ethnography were bordered only in some fields, such as folk belief, customs (customs folklore), incantations, and folk meteorological and medical cognitions, which, like folklore, had evolved over centuries and expressed folk beliefs but had not acquired the form and function of works of art (daildarbi) (Latvijas Padomju Enciklopēdija 1983: 353).

Ethnographers returned to the Institute of History and Material Culture in 1956, which was reorganised as the Institute of History in 1959, where ethnographers worked in various substructures (the Sector of Archaeology and Ethnography, and the Sector of Ethnography, which were later renamed departments) until the renewal of Latvia's independence in 1991.

During the 1950s and 1960s most of the LSSR's ethnographers defended their candidate theses in Moscow at the N. N. Miklukho-Maklai Institute of Ethnography, USSR AS (Mirdza Slava - 1955, Zavarina - 1956, Linda Dumpe - 1965, etc.), despite the fact that ethnography had been a lecture subject at the State University of Latvia from 1947 (Latvijas Padomju Enciklopédija 1984: 517). The first ethnographer to defend his candidate thesis in the LSSR seems to have been Saulvedis Cimermanis in 1958.

Archive materials - minutes of Scientific Council (SC) meetings from both institutes - provide evidence for there being a degree of freedom of choice in both the ethnographic sector as a whole, and for each employee in defining action plans and formulating work results in reports. ${ }^{6}$ The working plans and reports, which were thoroughly discussed in SC meetings in the 1950s, were also reviewed by the CM LSSR and the CC LCP. Final approval was given by the Presidium of the LSSR AS. When evaluating the results and planning the next period of work (five years, one year, or three months), the critical comments made by colleagues from the Scientific Coordination Council of the USSR AS, N. N. Miklukho-Maklai Institute of Ethnography, USSR AS, as well as the Department of Social Sciences of the LSSR AS, were also taken into account, as were the 
opinions expressed in the Republic press on the work of scientists. The work of folklorists and ethnographers was widely criticised.

For example, at a 15th December 1964 meeting of the SC of the Institute of History of the LSSR AS, the Scientific Secretary of the Institute, Anatoly Biron (Anatolijs Bīrons, 1929-2006), reproached ethnographers thus:

The government and the Presidium of the Academy of Sciences ask our ethnographers to work on issues directly related to bringing the new traditions to life. This issue should be handled not by individual employees, but by all ethnographers. Each scientific collaborator of the ethnographic sector must have some idea about these issues. (LNA-LVA 2371-1-303: 57)

Colleagues from associated institutes (Language, Party History), a representative of the Department of Social Sciences, a delegate from the Latvian Communist Party and a representative of the local party organisation worked alongside Institute employees in the SC of the Institute. At least until the end of the 1950s, all articles and theses, as well as the text of each report or lecture, were reviewed by these scientific councils. It should be noted that texts, as well as individual plans and reports, had already been discussed by sector colleagues. The criticism was merciless, coming for various sins such as misuse, or a lack of, Marxist-Leninist quotations, incorrect assessment of bourgeois ethnographers, false interpretation of a theme that did not correctly reflect Soviet reality, etc. (See for example, LNA-LVA 2372-1-84: 3., 6).

In the early 1950s N. N. Miklukho-Maklai Institute of Ethnography, USSR AS, which coordinated the work of ethnographers across all Soviet republics, ${ }^{7}$ put forward the following topics for the Latvian five year plan. 1) Daily life, culture and (artistic) craftsmanship of LSSR workers and kolkhoz members. The goal was to show the emergence of a new daily life and culture, socialist in content, national in form, as well as to ascertain how this new culture used the progressive heritage of the past. 2) Problems of Latvian ethnogenesis. 3) The role of Russian ethnographers in the development of Latvian ethnography. This topic was expanded so widely that it included the subject of cultural and historical contact between Latvians and Slavs, something that was also researched by archaeologists.

These topics were studied throughout the Soviet occupation of Latvia by highlighting some particular issues. ${ }^{8}$ Ethnographers in the framework of the first topic also worked on the subject of traditions. The annual expeditions, which during the communist regime covered almost the entire territory of Latvia, allowed ethnographers to collect material on Soviet traditions and categorise it in the following way (Kampars and Zakovich 1967: 35-39; Strods 1969: 525-539): 1) the state and revolutionary festivities and festive days (October Revolution, Victory Day, May 1, International Women's Day, Constitution Day); 2) labour customs and festivities (days devoted to professions and trades, for example teachers, militias, medical staff, etc.); 3) domestic customs and festivities (baptism, childhood celebrations, coming of age celebrations, weddings, funerals, remembrance days, etc.). ${ }^{9}$

The then Head of the Department of Ethnography at the Institute of History of the LSSR AS, Cimermanis (1979: 113), stated: 
The data collected during the expeditions (some of it!) will be used for the practical needs of the cultural life of the Republic: To draw up a new list of the cultural monuments of the Republic; to promote further flourishing of applied folk art; to improve socialist festivities and customs.

The methods used by ethnographers were the study of archival documents, and fieldwork, and the results were presented not only to the Institute or among scientists of the so-called Baltic Republics (Estonia, Latvia and Lithuania), but also to the USSR AS where ethnographers from across the vast Soviet Union gathered. Like other social sciences, the task of ethnography was to demonstrate the supremacy of the socialist system. To do this, comparative material was needed. Thanks to this argument, ethnographers also focused on the material cultures of other periods in Latvia. Ethnologist Lilita Vanaga (2011: 134) says the most extensive material, on the everyday life, culture, and spiritual culture of Latvians and other ethnic groups living in Latvia, was gathered as a result of the scientific activities of Soviet ethnographers. Narrations, pictures and photos in a collection made by ethnographers, covering the period from the 19th century to the present, are now stored at the REM at the Institute of Latvian History, University of Latvia.

There were at least three ways in which the Soviet Union 'persuaded' people in creative professions, including scientists from humanitarian and social sciences (then social sciences, obshchestvennyye nauki), to create works corresponding to the canon of Socialist Realism, while at the same time maintaining the simulacrum of Soviet reality: 1) physically destroying or deporting them from the country (especially during the Stalinist dictatorship period) or laying them off; 2) ensuring the necessary supervision over their work, starting with the formulation of tasks, content control in scientific and other councils at the LSSR AS and censorship by the publishing houses; 3) promoting conformism by offering various honorary titles and material benefits - well-paid posts, generous royalties, apartments, summer houses, access to resorts, etc. (Kruks 2011: 178; Šḳiņķe 2011: 39)

Ethnographer Cimermanis remembers as an anecdote a situation in which a thin line between the imagined and real Soviet realities was crossed, and the public scandal that followed. The reason was the publication of a photo of a kolkhoz worker wearing a pufayka (an outdoor work jacket that was popular, but not generally liked) in an edition of Arheologiija un etnogräfija edited by Cimermanis (Bērzin̄š 2015: 23). The reflection of Soviet reality had to be different from the real reality, but how that could be achieved was something to be guessed at, and the answer was often unpredictable.

\section{THE POSSIBILITIES OF ETHNOGRAPHERS TO INFLUENCE THE INTRODUCTION OF SOCIALIST TRADITIONS}

Despite the propaganda concerning the importance of Soviet traditions as a significant element in building a new Soviet individual, as promoted by officials of the Communist Party, ethnographers did manage to work on research interests of their own - for example the lifestyle of farm workers, fishing, traditional building (Cimermanis), traditional clothing (Slava) and crafts (Aina Alsupe, 1926-2015; Valdis Kronis, 1944-1998), family (Lidija Jefremova, 1929-2000) and culture of Russian Old Believers (Zavarina), harvest- 
ing types and tools (Ingrida Leinasare, 1929-2004; Dumpe), etc. Colleagues, who were forced to focus only on investigation of socialist reality - new traditions, 'socialist competitions', etc. - were unable to develop doctoral theses and consequently left ethnography (for example, Valfrīds Podnieks, Inese Lase).

In researching the topics included in the work plan, the ethnographers collected materials and recorded their observations on the introduction of socialist traditions in rural areas. The REM keeps approximately 2,000 items, for example descriptions (919), photos (844), objects (45) and others, which between 1957 and 1984 were collected by ethnographers as part of their fieldwork (Figure 1).

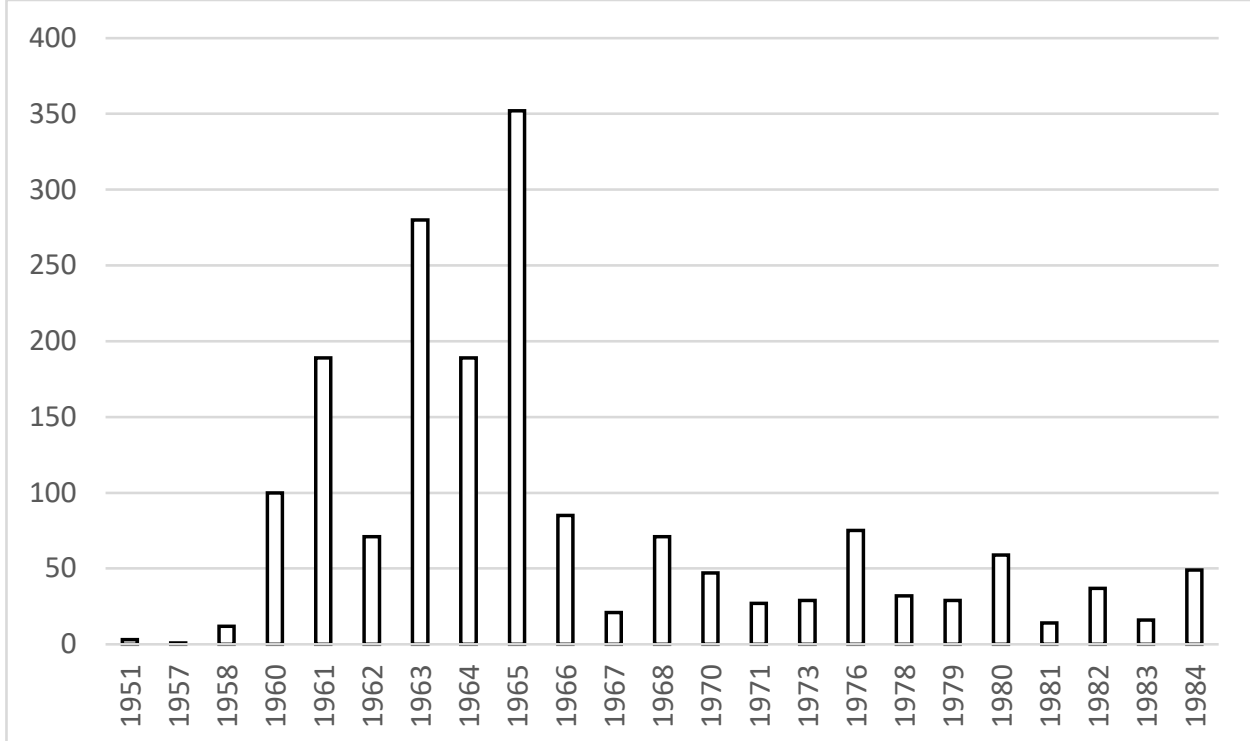

Figure 1. Time and volume of entry of materials on the introduction of Soviet traditions in the REM collection.

This collection represents materials from all of Latvia's historically ethnographic regions - Vidzeme (574), Latgale (679), Kurzeme (300), Zemgale and Selija (255). There is no reason for the region's dominance in terms of Soviet tradition material other than the fact that the planned expeditions to the region coincided with an increased interest in the subject. Scientific articles and reports, recommendations to the relevant soviet tradition enforcement commissions and public lectures were made based on the materials and observations gathered during fieldwork.

Ethnographers as representatives of the social sciences were involved in the work of Soviet propaganda. The IEF at the LSSR AS had a cooperation agreement with the Culture Committee of the CM LSSR from 1952 (LNA-LVA 2372-1-84: 3).

In accordance with the procedure laid down in the agreement, the staff of the Institute participated in the work of the SCs of the State Historical Museum and Open Air Museum; they took a part in the activities of the music, literature and repertoire sections at the People's Art Centre; they systematically assisted in the creation of exhibitions, 
etc.; they hosted conferences on contemporary folk art issues in cooperation with the People's Art Centre; and lectured in community centres and librarians' seminars. Ethnographers also promoted the results of their research within the framework of fieldwork because an exhibition of collected material and a workshop was an important part of the expedition. Especially in 1950s the presentations were discussed beforehand in the Sector of Ethnography and in the SC of the Institute.

The author sees at least three ways in which ethnographers were involved in the process of developing the content of new Soviet/socialist traditions.

The first is the scientific publications and presentations at Soviet ethnographic congresses and report sessions. Despite the fact that ethnographers had been working on the topic since the 1950s and had accumulated rich fieldwork material on the introduction and process of Soviet traditions in the LSSR, and had included the topic in publications (Jefremova 1957; Čivkule 1962; Fišers and Juškēvičs 1964; Theses... 1952-1991), writing the "Formation of Soviet Traditions" chapter for the founding edition of Latvian Ethnography (Strods 1969) was entrusted to folklorist Vilma Greble (1906-1991) and the Methodologist of the Republican Methodological Cabinet in the Activities of Clubs of the LSSR Ministry of Culture Brēde. Significant publications by ethnographers on the theme have been published since the 1970s. The 9th issue of Arheologija un etnogräfija included a collection of scientific publications about Soviet traditions - revolutionary traditions (by historian Ēriks Žagars, 1970), customs of Soviet daily life in cities (Zavarina 1970) and the countryside (Elga Čivkule and Lidija Jefremova). Several articles and collections of articles about traditions were compiled by ethnographers in the 1980s. Here one is able to note the contribution of ethnographer Cimermanis on the development of the topic. As head of the Department of Ethnography (1971-1995) Cimermanis wrote and oversaw editing and publishing of collective monographs, abstract books and special issues of the journal Arheologija un etnogräfija, dedicated to the subject of the Soviet people's daily life and the socialist traditions that were part of it (Cimermanis 1982; 1984; Alsupe and Cimermanis 1985, etc.).

A large inter-republic conference devoted to the development of socialist festivities and customs was organised by the ethnographers of the LSSR in Riga in 1980. The main topics of this huge event are outlined in the abstract book from the conference (Cimermanis 1982) and the collective monograph (Cimermanis 1987).

Scientific publications are a way of addressing the public, highlighting problems and offering solutions, but they are not the only way.

Another possible way for ethnographers to influence the implementation of Soviet tradition came if they belonged to an institution. The LSSR AS had a monopoly on carrying out inspections in all science branches it represented, including ethnography. As mentioned above, the Institute had an agreement with the Committee of Culture and Education of the CM LSSR that allowed ethnographers to be members of, and regulate and influence the work of, the councils of the State History Museum and the OpenAir Museum, as well some commissions of the People's Art House. Collaboration with the People's Art House gave the opportunity to provide counselling in the preparation of methodological materials, as well as in organising conferences and delivering lectures for practical workers, which allowed the Institute "to popularise the new art of the Soviet nation" (LNA-LVA 2372-1-84: 4). Within the lectures given during fieldwork, ethnographers had the opportunity to praise locals for proper implementation 
of traditions, matching the premises and their praise to the spirit of the event; or, on the contrary, criticising them for being influenced by religious prejudice and 'blackcoats' (the clergy), as well as for banality and flaws in the tradition rituals (for example wedding newspapers such as The Wedding Messenger, etc., excessive use of alcohol and insufficient singing were particularly criticised). Although the existing situation also envisaged the inspection of all papers relating to the field of ethnography, the editorial board of publications devoted to tradition shows that this function was performed by folklorists of the LSSR AS.

The third way ethnographers could attract the attention of officials (i.e. decisionmakers) to the problem of the content of the new traditions involved the work of the Commission Monitoring the Introduction of Soviet Domestic Traditions and the Law on Religious Cults of the CM LSSR, established on the June 6, 1964. This commission became the Commission Facilitating Soviet Traditions, Festivities, Rituals and the Law on Religious Cults of the CM LSSR on the October 9, 1979. Here ethnographers had the chance to present the monitoring they had performed during expeditions studying the process of implementing traditions to the Commission members, who represented a wide range of the institutions under the authority of the CM LSSR. The Commission also allowed ethnographers to propose the introduction of more advanced elements of folk tradition into the new Soviet customs and a more extensive use of elements of folk applied arts (wooden/clay candle holders, vases, cradles, etc.).

\section{SOME ENDING REMARKS}

Despite the actions and position of Soviet ethnographers in Latvia, socialist traditions were inevitably be introduced in the country. It was the aim of the ethnopolitics and ideological work of the totalitarian Soviet state. There can only be questions about how this happened. Ethnographers were able to maintain a certain balance, allowing national form to dominate over socialist content.

The activities of ethnographers in the context of socialist traditions can be viewed from three positions. 1) Scientific activity - rich expeditionary material was accumulated during fieldwork under the Soviet occupation regime. This includes information on the Latvian traditions and traditional customs practiced before the Soviet occupation. One should commend the volume of resources and the skilful use of Lenin's quotations by ethnographers, who were able to gather a very rich range of samples of Latvian material and intangible culture, covering it up with the claim of acquiring comparative material and a proposition that social phenomena should be studied in their evolution. The criticism of pre-Soviet papers and foreign scientists, as far as it exceeds the 'mandatory norms', is a separate issue. 2) Propaganda work - popular science articles and public lectures, focusing the public's attention on the topicality of the problem, criticising the upholders of religious rituals and the banalities/tastelessness of new traditions. 3) Work in government committees, although it is difficult to assess the affect ethnographers had on decision-making here.

Ethnographers were small screws in a large mechanism. Clearly, the government used the carrot and stick method to try and influence their actions, as they did with people in other creative professions. An overwhelming pressure from colleagues and supe- 
riors, criticism, and self-criticism served as the stick, and many succumbed to the pressure. Employee turnover in the 1950s was very high and this affected the implementation of plans and publication of papers. The reason for this was that a representative of Glavlit (the General Directorate for the Protection of State Secrets in the Press under the CM LSSR) or the Communist Party would declare the research irrelevant. An example of this is the research performed by Dumpe (1964) on harvesting types that was finished in 1959, but was published only five years later with the special support of eminent historian Teodors Zeids (1912-1994). Bonuses (officially awarded for implementing plans and timely submission of papers) and the opportunity to go to conferences, congresses and archives outside the republic served as the carrot.

The benefit to modern society is an extensive collection of ethnographic material that allows historians to look at the daily lives and cultural environment of the Soviet people. For those researching traditions, who want to learn about Latvian anniversary and family customs, and to material culture researchers, the benefit is that they can find out more about the construction of monuments, agricultural and fishery tools, crafts, and so on.

The reconciliation between society and ethnographers of the Soviet period and the recognition of their work is also evidenced by the awarding of the highest state order in Latvia, the Order of the Three Stars, to Strods (2010), Alsupe (2012) and Cimermenis (2014), and the Cross of Recognition to Dumpe (2011).

\section{A B B REVIATIONS}

CC LLYCL - Central Committee of the Latvian Leninist Young Communist League

CC LCP - Central Committee of the Latvian Communist Party

CM LSSR - Council of Ministers of the Latvian Soviet Socialist Republic

IEF - Institute of Ethnography and Folklore

LNA-LVA - The National Archives of Latvia - the State Archives of Latvia

LSSR - Latvian Soviet Socialist Republic

LSSR AS - LSSR Academy of Sciences

REM - Repository of Ethnographic Materials (at the Institute of Latvian History, University of Latvia)

SC - Scientific Councils (of the Institute of History and the Institute of Ethnography and Folklore at the LSSR AS)

USSR AS - Union of Soviet Socialist Republics Academy of Sciences

\section{NOTES}

1 Latvian Ethnography by Heinrihs Strods (1969); “The Development of the Socialist Festivities and Customs" by Saulvedis Cimermanis (1982); "The Ethnographic Aspects in Studying the Socialist Lifestyle in the Latvian SSR" by Cimermanis (1984); The Rural Inhabitants of Soviet Latvia and Their Culture Nowadays by Aina Alsupe and Cimermanis (1985); Socialist Festivities and Customs by Cimermanis (1987).

2 Soviet Domestic Traditions by Maiga Sāre and Jānis Andersons (1960); I Am Turning Eighteen Today: Methodological Instructions for the Organisers of the Coming-of-Age Celebrations (Man šodien... 1966); Glory to the Great October: A Compilation of Materials for Festive Celebrations by Vintere (1967); The Joy of Celebration Earned at Work: Methodological Materials for Labour Traditions by Aina Brēde 
(1978); Use of Moral and Aesthetic Values of Latvian Folklore in the Soviet Festive Traditions by Renāte Tavare (1980); Methodological Materials: Recommendations for the Marriage Ritual, Poetry and Music Issued by the Commission Facilitating the Soviet Traditions, Festivities, Rituals and the Law on Religious Cults of the Council of Ministers of the Latvian SSR by Brēde (1981); etc.

3 For more on the implementation of Socialist traditions in the LSSR, see "The Invented Traditions: The Calendar of Festive Days and Family Customs in the Latvian SSR" (Boldāne-Zeḷenkova 2017). Here, along with the process of constructing new Soviet traditions, the author focuses on the calendar of Soviet celebrations, including domestic, state and professional festivities. The author deals with the perspective and influence of LSSR ethnographers on the process of implementation, and the content, of Soviet domestic traditions. The article is based on new archive material.

4 The Commission of the Soviet Domestic Traditions of the CC LLYCL consisted of 17 members (composers, artists, poets, etc.) (LNA-LVA 270-24-6: 68-78, 136).

5 Founded in 1945 under the name the Republican People's House of Art, it was renamed the People's House of Art of Melngailis in 1954. The Academic Methodological Centre of Art and Culture Education of the Republican People's House of Art of Melngailis was renamed as the People's Centre of Art of Melngailis in 1989. (State Archive of Latvia)

6 Particularly documents from the 1950s. For unknown reasons minutes of the meetings of the Sector of Ethnography in the Archive's fund of the Institute of History are missing from the 1960s.

7 Moscow's colleagues worked here with the special purpose of giving an appropriate place to ethnography among the sciences of the LSSR. The Miklukho-Maklai Institute of Ethnography was an institution where Latvian ethnographers defended their doctoral candidate theses (Mirdza Slava (1924-2001) in 1955). The first ethnographer able to hold this ceremony in Riga was Cimermanis, in 1958.

8 When looking back at the 27 years of Latvian Soviet ethnography, the head of the Department of Archaeology and Ethnography, Strods (1967: 4), listed the topics studied by ethnographers: 1) ethnogenesis of the Latvian people, ethnic history; 2) Latvian culture and way of life in periods of feudalism and capitalism, Latvian national culture; 3) changes in culture and lifestyle during the period of socialism and communism, ethnic and national development problems. Marking further activities of the ethnographic sector in the middle of the 1970s, Cimermanis (1976: 99) noted that "the contemporary lifestyle and culture of rural and city dwellers of Soviet Latvia" was one of the most important research directions, "drawing special attention to the proletariat family, Soviet labour and domestic customs and the clarification of the development of folk art", etc.

9 It should be noted that analyses of Soviet historiography on the subject by contemporaries reached a conclusion - there was no consensus on how to divide socialist traditions until the beginning of 1980s (Saburova 1987: 13). A different perspective is provided in the contemporary historiography, grouping Soviet festivities and customs in the following way: historical, professional, folkloristic, and others (Kreegipuu 2011).

\section{SOURCES}

LNA-LVA Document No. 2371. Institute of Latvian History of the Latvian Academy of Sciences. LNA-LVA Document No. 2372. Institute of Ethnography and Folklore of the Latvian SSR Academy of Sciences.

LNA-LVA Document No. 270. Council of Ministers of the Latvian SSR and the Council of Ministers of the Republic of Latvia. 
REM. Materials from the former districts of Balvi (E 27), Dobele and Ludza (E 28), Rèzekne and Preiḷi (E 29), Preiḷi and Daugavpils (E 35), Aizkraukle (Stučka) (E 39), Jelgava (E 40), Tukums and Jēkabpils (E 49), Daugavpils and Krāslava (E 57).

\section{REFERENCES}

Alsupe, Aina and Saulvedis Cimermanis, eds. 1985. Padomju Latvijas lauku iedzīvotāji un viņu kultūra mūsdienās. Rīga: Zinātne.

Bērziṇš, Jānis. 2015. Etnogrāfs un kultūras vēsturnieks Saulvedis Cimermanis. - Latvijas zinātnieki: Saulvedis Cimermanis. Etnogrāfs un kultūras vēsturnieks. Rīga: Zinātne, 7-30.

Boldāne-Zeḷenkova, Ilze. 2017. The Invented Traditions: the Calendar of Festive Days and Family Customs in the Latvian SSR. - Latvijas Vēstures Institūta Žurnāls 3: 122-150.

Brēde, Aina, ed. 1978. Svētku prieks darbā nopelnīts: Metodiskie materiāli darba tradīiijām. Rīga: LPSR KM Rep. klubu darba zin. metod. kabinets.

Brēde, Aina, ed. 1981. Metodiski materiāli: LPSR Ministru Padomes padomju tradīciju, svētku, rituālu un reliğisko kultu likumievērošanas veicināšanas komisijas rekomendācijas laulības rituāla norisei, ieteicamais dzejas un mūzikas repertuārs. Rīga: E. Melngaiḷa Republikas tautas mākslas un kult.izglīt. darba zinātniski metodiskais centrs.

Cimermanis, Saulvedis. 1976. Tautas dzīvesveida atklāsmes ceḷos. - Latvijas PSR Zinātnu akadēmijas Vēstures institūts. Rīga: Zinātne, 95-99.

Cimermanis, Saulvedis. 1979. Etnogrāfijas sektora 1978. gada ekspedīcija Burtniekos. - Zinātniskās atskaites sesijas referātu tēzes par arheologu, antropologu un etnogrāfu 1978. gada pētījumu rezultātiem. Rīga: LPSR Zinātṇu akadēmija, LPSR Kultūras ministrija, 113-116.

Cimermanis, Saulvedis. 1982. Sociālistisko svētku un ieražu attīstības jautājumi. - Latvijas PSR Zinātñu akadēmijas Vēstis 11: 131-136.

Cimermanis, Saulvedis. 1984. Sociālistiskā dzīvesveida pētīšanas etnogrāfiskie aspekti Latvijas PSR. - LPSR Zinātñu akadèmijas Vēstis 4: 116-123.

Cimermanis, Saulvedis, ed. 1987. Sociālistiskie svētki un ieražas. Rīga: Zinātne.

Cimermanis, Saulvedis and Mirdza Slava. 1987. Latviešu tautas lietišḳās mākslas tradīciju izmantošanas iespējas padomju svētku un rituālu pilnveidošanā. - Sociālistiskie svētki un ieražas, edited by Saulvedis Cimermanis. Rīga: Zinātne, 134-149.

Čivkule, Elga. 1962. Jaunas iezīmes Gulbenes rajona kolhoznieku dzīvē. - Arheoloğija un etnogräfija I. Rīga: LPSR Zinātṇu akadēmijas izdevniecība, 67-75.

Čivkule, Elga and Lidija Jefremova. 1970. Padomju sadzīves tradīcijas lauku darbaḷaužu dzīvē. Arheoloơija un etnogrāfija IX. Rīga: Zinātne, 211-239.

Dumpe, Linda. 1964. Ražas novākšanas veidu attīstība Latvijā (no senākiem laikiem līdz XX gs. sākumam. - LPSR Vēstures muzeja raksti: Etnogrāfija. Rīga, 7-215.

Fišers, R. and Broṇislavs Juškēvičs. 1964. Padomju sadzīves tradīciju attīstība Latvijā. - Arheoloógija un etnogrāfija VI. Rīga: LPSR Zinātṇu akadēmijas izdevniecība, 207-224.

Jefremova, Lidija. 1957. Dažas Latgales latviešu zemnieku gimenes svinības 19. gs. otrā pusē. Arheolog̣ija un etnogrāfija IV. Rīga: LPSR Zinātṇu akadēmijas izdevniecība, 115-127.

Kalits, Vilve. 1987. Sociālistisko gimenes ieražu veidošanās Igaunijas PSR. - Sociālistiskie svētki un ieražas, edited by Saulvedis Cimermanis. Rīga: Zinātne, 70-84

Kampars, Pëtr and Nikolay Zakovich. 1967. Sovetskaya grazhdanskaya obryadnost'. Moskva: Mysl'. [Кампарс, Пётр и Николай Закович. 1967. Советская гражданская обрядность. Москва: Мысль.]

Kreegipuu, Tiiu. 2011. Soviet Holiday Calendar in Estonia in the Years 1945-1985. - Tuna 2 (2): 68-90. 
Kruks, Sergejs. 2011. Ārtelpas skulptūras semiotika, ekonomika un politika: Pieminekḷu celtniecība un demontāža Latvijā 1945-2010. Rīga: Neputns.

Ķencis, Toms. 2019. Vācot padomju folkloru. Rīga: LU Literatūras, folkloras un mākslas institūts.

Latvijas Padomju enciklopēdija. 1983. Vol. 3. Rīga: Galvenā enciklopēdiju redakcija.

Latvijas Padomju enciklopēdija. 1984. Vol. 5.2. Rīga: Galvenā enciklopēdiju redakcija.

Latvijas Padomju enciklopēdija. 1987. Vol. 9. Rīga: Galvenā enciklopēdiju redakcija.

Man šodien astonpadsmit gadu: Metodiski padomi pilngadības svētku organizētājiem. 1966. Rīga.

Muižnieks, Indrikikis. 2019. 100 zinātnes gadi Latvijas Universitātē. - Zinātnes Vēstnesis 14: 4.

Ronis, Indulis. 1995. Latvijas vēstures institūts laikmeta kontekstā. - Latvijas Vēstures Institūta Žurnāls 4: 19-37.

Saburova, Lyudmila. 1987. 1970. gadu literatūra par jaunajiem svētkiem un ieražām (galvenās īpatnības un tematika). - Sociālistiskie svētki un ieražas, edited by Saulvedis Cimermanis. Rīga: Zinātne, 9-25.

Sāre, Maiga and Jānis Andersons. 1960. Padomju sadzìves tradīcijas. Rīga: Latvijas Valsts izdevniecība.

State Archive of Latvia. http://www.archiv.org.lv/index3.php?id=9009\&kods=300110223\&vien=2 (accessed December 15, 2016).

Strods, Heinrihs. 1964. Daži etnogrāfisko materiālu vākšanas jautājumi buržuāziskajā Latvijā (1920-1940.g.). - Arheoloǵija un etnogräfija VI. Rīga: LPSR Zinātṇu akadēmijas izdevniecība, $141-160$.

Strods, Heinrihs. 1967. Latviešu padomju etnogrāfija 27 gados (1940-1967). - Zinātniskās atskaites sesijas referātu tēzes par arheologu, antropologu un etnogrāfu 1966. gada pētījumu rezultātiem. Rīga: LPSR Zinātṇu akadēmija, LPSR Kultūras ministrija, 3-5.

Strods, Heinrihs, ed. 1969. Latviešu etnogrāfija. Rīga: Zinātne.

Šḳiṇḳe, Iveta. 2011. Divdesmitā gadsimta piecdesmitie - astoṇdesmitie. Ieskats Latvijas vēsturē. - Nonkonformisms grafikā 1944-1990. Rīga: Latvijas Nacionālā bibliotēka.

Tavare, Renāte. 1980. Latviešu folkloras tikumisko un estētisko vērtību izmantošana padomju svētku tradīcijās: Palīgmateriāls lektoriem. Rīga: LPSR Zinību b-ba. Lit. un mākslas prop. zin. metod. Padome.

Theses of Scientific Reports Session on Research Results of Archaeologists, Anthropologists and Ethnographers. 1952-1991. Rīga: LPSR Zinātṇu akadēmija, LPSR Kultūras ministrija.

Trocigs, Dags. 1940. Latviešu tautas gara mantu vākšana un pētǐšana Latvijā. - Raksti un māksla 2: $172-178$.

Zavarina, Antoṇina. 1970. Padomju sadzīves tradīciju attīstība Latvijas pilsētās. - Arheolog̣ija un etnogräfija IX. Rīga: Zinātne, 195-206.

Zhidkova, Yelena. 2012. Sovetskaya grazhdanskaya obryadnost' kak al'ternativa obryadnosti religioznoy. - Gosudarstvo, religiya, tserkov' v Rossii i za rubezhom 3-4 (30): 407-428. [Жидкова, Елена. 2012. Советская гражданская обрядность как альтернатива обрядности редигиозной. - Государство, религия, цзерковь в России и за рубежом 3-4 (30): 407-428.]

Žagars, Ēriks. 1970. Revolucionāro tradīiju izmantošana komunistiskās audzināšanas darbā Padomju Latvijā 1940. un 1941. gadā. - Arheolog̣ija un etnogrāfija IX. Rīga: Zinātne, 135-184.

Vanaga, Lilita. 2011. LU Latvijas vēstures institūtam - 75. Institūta etnogrāfi ekspedīcijās. - Latvijas Vēstures Institūta Žurnāls 4: 134-142.

Vintere, M., ed. 1967. Lielajam Oktobrim slava. Svētku sarīkojumu uzdevumu materiālu apkopojums. Rīga: Em. Melngaiḷa tautas mākslas nams.

Višņauskaite, Angele. 1987. Kultūras mantojuma izlietošana lietuviešu mūsdienu kāzu ieražās. Sociālistiskie svētki un ieražas, edited by Saulvedis Cimermanis. Rīga: Zinātne, 112-120. 